\title{
Savelev K.S., Zhukova Yu.V. \\ Experimental installations for processing complex packages made of composite materials and titanium alloys and research of ultrasonic drilling processes
}

\author{
Ulyanovsk State Technical University
}

(Russia, Ulyanovsk)

doi: 10.18411/lj-04-2019-241

idsp: ljournal-04-2019-241

Abstract

The possibility of improving the quality of holes in packages made of composite materials in the drilling operation due to the use of the energy of ultrasonic vibrations is considered. More than that, two experimental facilities for conducting studies of the ultrasonic vibrations influence on the quality of the holes in complex packages made of composite materials and titanium alloys are developed. complex.

Keywords: drilling, composite material, mixed package, ultrasonic vibrations, robotic

In recent years, the ratio of composite materials in mechanical engineering has increased significantly. These materials have high physical, mechanical and performance characteristics. The use of such materials allows obtaining products with a set of properties that traditional materials do not possess.

The use of composite materials in mechanical engineering allows us to solve a large list of tasks: increasing strength, corrosion resistance, reducing weight, reducing radar visibility, etc. It should be noted that when compared with metals, the cost of production of parts is significantly reduced. This contributes to reducing the ratio of machine processing and increasing the utilization rate of the material. For the final product, the mechanical properties of the composite material can be adapted by changing the reinforcing elements and due to the proportion of "fillers/matrix".

Currently, in the aviation industry both in Russia and abroad there is a tendency to increase the ratio of the composite materials use in various structural elements of aircraft [1]. In this case, composite materials are often combined into mixed packages consisting of composite materials of various grades as well as aluminum and (or) titanium alloys. The number of dissimilar materials in packages usually does not exceed three (titanium alloy, aluminum alloy, composite material), and the total number of layers can reach five or more.

The composition of the mixed package and the sequence of arrangement of layers depend on the design features and purpose of the parts to be joined. Overwhelmingly, the joints are made by installing the connecting elements in the pre-machined holes. Since the constituent elements of mixed packages have different physical and mechanical properties (for example, low thermal conductivity and tendency to adhesion of titanium alloys, pronounced anisotropy of composite material properties), such defects as delamination, destruction, uncut fibers, tears, melting of the polymer matrix, occurrence of burning on the treated surfaces, etc. In turn, a decrease in the quality of the holes can lead to high contact loads, a decrease in the resource and the destruction of the joints in mixed packages.

Composite material is considered difficult-to-machine; therefore, during the implementation of various methods for producing holes problems will certainly arise.

A research for the solution of these problems was carried out. During the research, the following problems of obtaining holes were discovered: the low productivity of the processing of the honeycomb structure (holes with a diameter of $2 \mathrm{~mm}$ ). It may be explained by the fact that the process takes place at low cutting speeds with periodic tool breakdowns, since falling on the cell wall of the composite structure, the drill breaks and often fragments remain in the "body" material. This is due to the requirements of the positional tolerance for holes. The use of lubricating liquid is not possible due to the moisture-absorbing properties of the material. The low thermal conductivity of the material causes poor heat removal from the treatment area. Due to the holes occurrence, scratches, tatters and delamination appear. 
In the search for solutions to emerging issues and concerns the following is proposed:

- The rational choice of the cutting tool and the power drill is carried out.

- Optimal cutting speed is selected.

- To eliminate drill breakage, cell fillers in the material (plastic, frozen water) are used.

- A conductor made from sheet steel is used to ensure the position tolerance of the hole group.

- At the initial stage, researchers began to use robotic complexes (for example, KUKA) with CNC for work on the program.

The first results showed high efficiency and increased durability of the cutting tool.

Vibration drilling is widely used in industry for drilling holes in composite packages. The study shows that when processing a package of carbon-plastic material - titanium when using low-frequency vibrations significantly reduced the temperature in the cutting zone. But, unfortunately, it was still not clear what exactly led to such results either the intermittent nature of the cutting or the better access to the lubricating liquid and more efficient removal of chips from the treatment area. And at the same time, it is noted that the service life of the cutting tool can be increased by $300 \%$.

The department of Engineering Technology, Ulyanovsk State Technical University (UlSTU) has accumulated considerable experience in the intensification of machining processes using the energy of ultrasonic vibrations [2]. This experience is applied in the developed experimental facilities for processing complex packages made of composite materials and titanium alloys. Installations also allow conducting research of ultrasonic drilling.

Currently, UISTU has developed two experimental facilities for conducting studies of the ultrasonic vibrations influence on the quality of the holes in complex packages made of composite materials and titanium alloys. Fig. 1 and Fig. 2 show the general types of experimental installations.

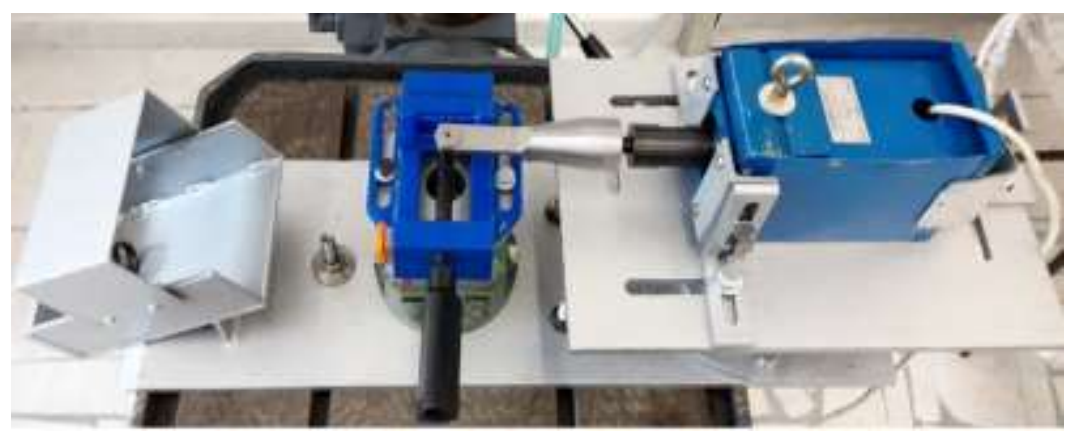

Fig. 1. General view of the experimental facility №1

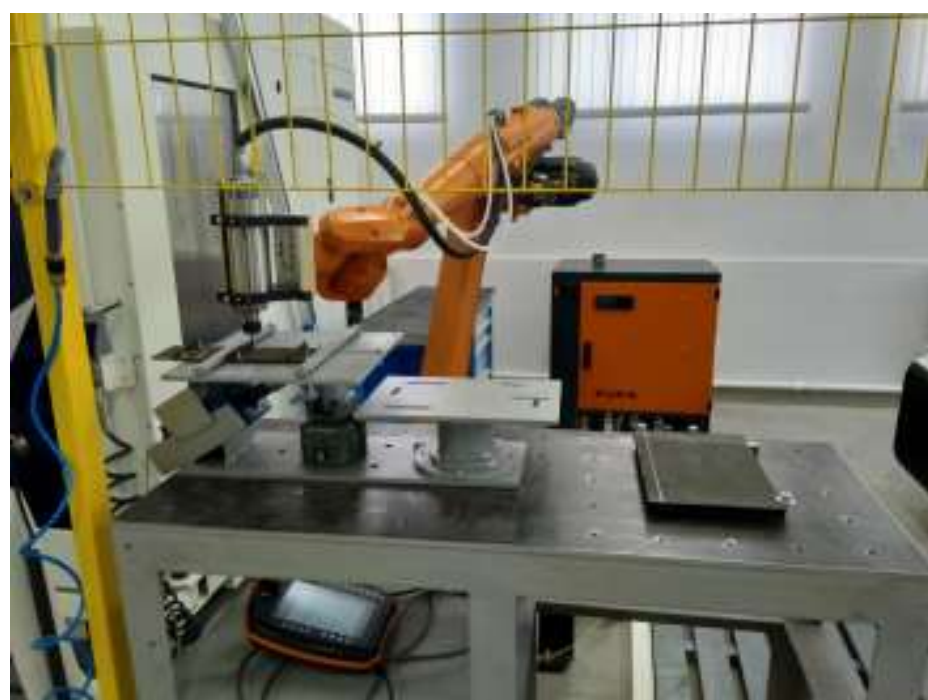

Fig. 2. General view of the experimental facility №2 with the Kuka robot 
Facilities consist of the case fixed on a table of the vertical boring machine, ultrasonic heads which can be mounted on the body in two positions, dynamometer UDM-100 and the object stage the package is made of composite materials is placed on.

Facilities allow conducting experiments with the imposition of non-modulated, amplitude-modulated or frequency-modulated ultrasonic vibrations in two ways:

- on the drill in the radial direction through the guide conductor bushingwaveguide;

- on a object stage with a package made of composite materials.

It should be noted that these facilities can be used for machining holes using a robotic system.

The results of preliminary experiments confirmed the positive effect of the energy of ultrasonic vibrations on the drilling process of mixed packages consisting of composite materials, titanium and (or) aluminum alloys. As we know, the processing of holes in packages made of composite materials can be carried out on robotic complexes using the following methods [3-6]:

1. Processing using a spindle assembly providing only the rotational movement of the drill.

Here the feed is carried out by the links of the robot. With this method the spindle unit has a minimum size and weight which contributes to work in hard-to-reach places and allows the use of a robot with a low carrying capacity. supply.

2. The use of a special spindle assembly providing both the rotation of the tool and its

In this case, the links of the robot perform only the positioning of the working body relative to the workpiece.

3. Processing holes by orbital drilling, in which a special milling cutter is used as a cutting tool, the diameter of which is $60-80 \%$ of the diameter of the resulting hole.

In conclusion it is important to point out that the results of preliminary experiments confirmed the positive effect of the energy of ultrasonic vibrations on the drilling process of mixed packages consisting of composite materials, titanium and (or) aluminum alloys.

\section{$* * *$}

1. Иванов Ю.Н. Оптимизация технологических параметров сверления отверстий в пакетах из углепластиков и титановых сплавов: дис. канд. техн. наук: 05.02.07 / ИрНИТУ. - Иркутск, 2018. - 141 с.

2. Киселев Е.С. Интенсификация процессов механической обработки использованием энергии ультразвукового поля: учеб. пособие / УлГТУ. - Ульяновск, 2003. - 186 с.

3. Исследование технологии обработки отверстий малых диаметров в ПКМ на робототехническом комплексе / Н.С. Чащин, Ю.Н. Иванов, А.В. Сидорова, Е.Н. Семенов, А.А. Стуров // Вестник Иркутского государственного технического университета. - 2017. - Т. 21, № 6. - С. 39-48.

4. Сидорова А.В. Исследование обработки ПКМ на РТК, дефект отклонения от круглости // Авиамашиностроение и транспорт Сибири: сб. ст. Всерос. молодеж. науч.-практ. конф. (г. Иркутск, 11 ноября 2016). - Иркутск, 2016. - С. 258-262.

5. Чащин Н.С., Иванов Ю.Н. Обработка отверстий в смешанных пакетах методом орбитального сверления // Вестник Иркутского государственного технического университета. - 2015. - № 11 (106). - С. $44-49$.

6. Иванова А.В., Пономарев Б.Б. Исследование точности воспроизведения пространственных контуров промышленными роботами // Наука и образование / МГТУ им. Н.Э. Баумана. - 2014. - № 5. - С. 5-11. 